\title{
Detection of Hepatozoan canis in Dogs from Namakkal Region of Tamilnadu by Conventional and Molecular Approach
}

\author{
Kalaivanan Murugesan ${ }^{1}$, Saravanan Subramanian ${ }^{1} *$, \\ Palanivel Kondan Muthusamy ${ }^{1}$ and G. Ponnudurai ${ }^{2}$
}

${ }^{1}$ Department of Veterinary Preventive Medicine, Veterinary College and Research Institute, Tamil Nadu Veterinary and Animal Sciences University, (TANUVAS), Namakkal-2, India

${ }^{2}$ Department of Veterinary Parasitology, Veterinary College and Research Institute,

Namakkal-2, India

*Corresponding author

\section{A B S T R A C T}

\section{Keywords}

Prevalence, H. canis, PCR, Microscopic examination, Phylogenetics, Sensitivity.

Article Info Accepted: 06 March 2017 Available Online: 10 April 2017
A total of 150 dogs brought to Teaching Veterinary Clinical Complex (TCCC), Veterinary College and Research Institute, Namakkal, from September, 2015 to April, 2016 were screened for the haemoparasite, H. canis by blood smear examination and polymerase chain reaction which revealed a positivity of 0.66 and 5.33 per cent, respectively. The PCR was found to have a high sensitivity $(100.0 \%)$ and specificity $(91.27 \%)$ when compared with microscopic examination. The target 18S rRNA of $H$. canis identified was found to possess a 100.0 per cent homology with the $H$. canis of dogs in Hungary, Italy, Japan, North Africa, Pakistan, Portugal and Thailand. Rhipicephalus sanguineus was the tick vector identified from the positive cases and the males $(6.48 \%)$, cross breed dogs $(10.0 \%)$ and the age group of $>4$ years $(9.09 \%)$ were found to be highly susceptible.

\section{Introduction}

India has a wide range of climatic zones which is conducive for a diverse range of vectors and canines are continuously exposed to a spectrum of haemoparasitic diseases (Abd Rani et al., 2010). Canine hepatozoonosis caused by Hepatozoon canis was first described in India in 1904 by Bentley as leucocytozoan of the dogs (Dwyer, 2011). The distribution of $H$. canis is widespread in Africa, Southwestern Asia, Europe and North and South America, whereas H. americanum is restricted to the United States (Baneth et al., 2003). H. canis is amongst one of the most widespread canine vector borne disease because of frequent infestation by the tick Rhipicephalus sanguineus (Otranto et al., 2011). The infection level can vary from subclinical, usually associated with low parasitemia, to severe and life-threatening disease in animals with high parasitemia, often in puppies or immunosuppressed animals and infected dogs may persistently show latent parasitism for long periods of time (Baneth et al., 1997).

In India, the information on the prevalence and epidemiology of hepatozoonosis in India is still under reported. Further, most cases of 
hepatozoonosis in Indian subcontinent have so far been diagnosed only by traditional methods using microscopic examination of peripheral blood smears which are time consuming and does not permit reliable identification of the above parasites in clinical and asymptomatic carriers (Abd Rani et al., 2011). Hence, this paper presents the prevalence, molecular characterisation and the risk factors associated with the epidemiology of hepatozoonosis in dogs in Namakkal region of Tamilnadu in India.

\section{Materials and Methods}

A total of 150 dogs, irrespective of their age, sex, breed and health status presented to Teaching Veterinary Clinical Complex (TCCC), VCRI, Namakkal from September, 2015 to April, 2016 were screened. The clinical samples like blood, peripheral blood films and tick samples along with relevant epidemiological data were collected from the dogs. The blood films prepared were stained by Giemsa staining and the haemoparasites were identified based on the morphological characters (Greene et al., 2008). The blood samples were collected in EDTA coated vacutainers and the sample DNA was extracted as per the protocol recommended by Dneasy blood and tissue kit (Qiagen, Netherland) manufacturer. A PCR master mix of $2 \mathrm{x}$ (Ampliqon, Denmark) concentration was used in the reaction mixture and $100 \mathrm{bp}$ DNA ladder (GeneDirex, USA) with stock solution $54 \mu 1 / 500 \mu 1$ was used in the electrophoresis. These primers were designed by using FastPCR Software (targeting the $18 \mathrm{~S}$ ribosomal RNA gene - KF322145.1), custom synthesized (Eurofins and Sigma, India), with the product size $346 \mathrm{bp}$ and used in this study. The sequences of the primers were as follows.

Forward:CTGACCTATCAGCTTTCGAC

Reverse:CAGCAGAACTTCAACTACGAG $\mathrm{C}$
The extracted DNA was amplified using the selected primers by standardisation of PCR with following reaction mixture and cycling conditions. Reaction mixture: DNA template $-3 \mu 1$, master mix-13 $\mu 1$, forward and reverse primer (10 pico moles, each) - $1 \mu \mathrm{l}$ each and molecular grade water $-7 \mu$ l. Cycling conditions: Initial denaturation $-95^{\circ} \mathrm{C} / 8 \mathrm{~min}$, denaturation $-94^{\circ} \mathrm{C} / 30 \mathrm{sec}, \quad$ annealing$55^{\circ} \mathrm{C} / 30 \mathrm{sec}$ and extension- $72^{\circ} \mathrm{C} / 45 \mathrm{sec}$ with 25 cycles; and final extension $-72^{\circ} \mathrm{C} / 10 \mathrm{~min}$. The gel was visualized under UV transilluminator and the bands of appropriate size were identified by comparison with the $100 \mathrm{bp}$ ladder. The two positive amplified products were subjected to phylogenetic analysis (Eurofin) for confirmation.

\section{Results and Discussion}

The screening of 150 Giemsa stained peripheral blood smears for haemoparasitic infections revealed a prevalence of 0.66 per cent for $H$. canis and the gamonts of $H$. canis were identified in the neutrophils (Figure 1). A similar low prevalence of 1.08, 1.41, 2.3 and 4.8 per cent but higher than that observed in this study was recorded for $H$. canis in India (Singh et al., 2012; Bhattacharjee et al.; Senthil Kumar et al., 2009). The reason for the low prevalence recorded in this study could be attributed to the low detection limit of light microscopy which is approximately 0.001 per cent parasitaemia (Matsuu et al., 2005), though blood smear examination has been the simplest, reasonably sensitive test during acute and clinically significant infections. In contrast, PCR revealed a prevalence of 5.33 per cent for $H$. canis amplified at $346 \mathrm{bp}$ targeting 18S rRNA gene (Figure 2). A similar low prevalence was recorded for $H$. canis in Turkey by PCR (Aydin et al., 2015), however, a high prevalence of 30.0 per cent was recorded in India. This could be attributed to the high sensitivity of PCR which is the most efficient 
tool in the detection of subclinical and in apparent infections with a very low level of parasitaemia that can go undetected by the conventional microscopic examination. In this study, the PCR was found to have a high sensitivity (100.0\%) and specificity $(95.30 \%)$ in the detection of $H$. canis and this is in agreement with similar findings of Otranto et al., (2011).

Table.1 Comparison of homology of the H. canis from positive cases with published sequencing results

\begin{tabular}{|c|c|c|c|c|}
\hline $\begin{array}{l}\text { S. } \\
\text { No }\end{array}$ & $\begin{array}{c}\text { Haemoparasite with } \\
\text { target gene }\end{array}$ & $\begin{array}{c}\text { GenBank } \\
\text { accession } \\
\text { number }\end{array}$ & $\begin{array}{c}\text { Haemoparasites with } \\
\text { target gene }\end{array}$ & $\begin{array}{l}\text { Place of } \\
\text { isolation }\end{array}$ \\
\hline \multirow{9}{*}{1.} & \multirow{9}{*}{ 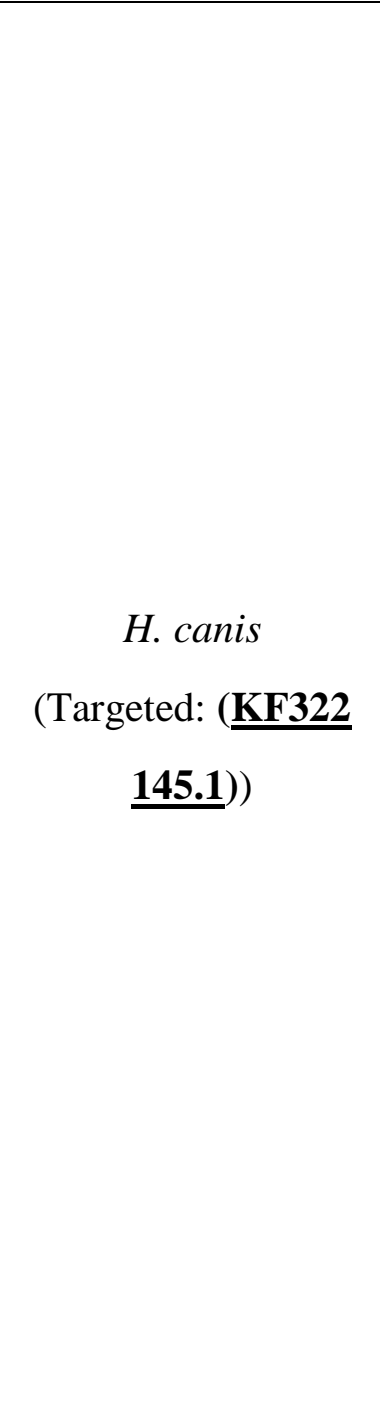 } & KU535870.1 & $\begin{array}{l}\text { H. canis isolate, } 18 \mathrm{~S} \\
\text { rRNA gene }\end{array}$ & Pakistan \\
\hline & & KU765200.1 & $\begin{array}{l}\text { H. canis isolate, } 18 \mathrm{~S} \\
\text { rRNA gene }\end{array}$ & Thailand \\
\hline & & KX069244.1 & $\begin{array}{l}\text { H. canis isolate, } 18 \mathrm{~S} \\
\text { rRNA gene }\end{array}$ & Hungary \\
\hline & & KU961967.1 & $\begin{array}{l}\text { H. canis isolate, } 18 \mathrm{~S} \\
\text { rRNA gene }\end{array}$ & Italy \\
\hline & & LC018210.1 & $\begin{array}{l}\text { H. canis isolate, } 18 \mathrm{~S} \\
\text { rRNA gene }\end{array}$ & Portugal \\
\hline & & KP715301.1 & $\begin{array}{l}\text { H. canis fox isolate, } \\
\text { 18S rRNA gene }\end{array}$ & Italy \\
\hline & & KX082907.1 & $\begin{array}{l}\text { H. canis clone, } 18 \mathrm{~S} \\
\text { rRNA gene }\end{array}$ & Isreal \\
\hline & & KJ499481.1 & $\begin{array}{l}\text { H. canis isolate, } 18 \mathrm{~S} \\
\text { rRNA gene }\end{array}$ & North Africa \\
\hline & & KU765202.1 & $\begin{array}{l}\text { H. canis isolate, } 18 \mathrm{~S} \\
\text { rRNA gene }\end{array}$ & Japan \\
\hline
\end{tabular}


Table.2 Age, sex, breed and season-specific prevalence of $H$. canis

\begin{tabular}{|c|c|c|c|c|}
\hline \multicolumn{2}{|c|}{$\begin{array}{l}\text { Epidemiological } \\
\text { determinants }\end{array}$} & $\begin{array}{c}\text { Total } \\
(n=150)\end{array}$ & $\begin{array}{c}\text { No. of } \\
\text { positives } \\
(n=8)\end{array}$ & Per cent positives \\
\hline \multirow{4}{*}{ Age } & $<1$ year & 34 & 2 & 5.88 \\
\hline & $1-2$ years & 40 & 1 & 2.5 \\
\hline & $2-4$ years & 32 & 1 & 3.12 \\
\hline & $>4$ years & 44 & 4 & 9.09 \\
\hline \multicolumn{2}{|c|}{ P value } & & \multicolumn{2}{|c|}{$0.532^{\mathrm{NS}}$} \\
\hline \multirow{2}{*}{ Sex } & Male & 108 & 7 & 6.48 \\
\hline & Female & 42 & 1 & 2.38 \\
\hline \multicolumn{2}{|c|}{ P value } & & \multicolumn{2}{|c|}{$0.315^{\mathrm{NS}}$} \\
\hline \multirow{3}{*}{ Breed } & Pure & 106 & 4 & 3.77 \\
\hline & Cross & 10 & 1 & 10.0 \\
\hline & $\mathrm{ND}$ & 34 & 3 & 8.82 \\
\hline \multicolumn{2}{|c|}{ P value } & & \multicolumn{2}{|c|}{$0.414^{\mathrm{NS}}$} \\
\hline \multirow{4}{*}{ Season } & $\begin{array}{c}\text { Southwest } \\
\text { monsoon }\end{array}$ & 12 & 5 & 41.66 \\
\hline & $\begin{array}{c}\text { Northeast } \\
\text { monsoon }\end{array}$ & 82 & 1 & 1.21 \\
\hline & Winter & 41 & 2 & 4.87 \\
\hline & Summer & 15 & - & - \\
\hline \multicolumn{2}{|c|}{ P value } & & \multicolumn{2}{|c|}{$0.0001 * *$} \\
\hline
\end{tabular}

${ }^{\mathrm{NS}}$ Non-significant, $*$ Significant at 95.0 per cent level, $* *$ Significant at 99.0 per cent level

Figure.1 A Giemsa stained blood smear revealing the gamont of H. canis in a neutrophil (x100)

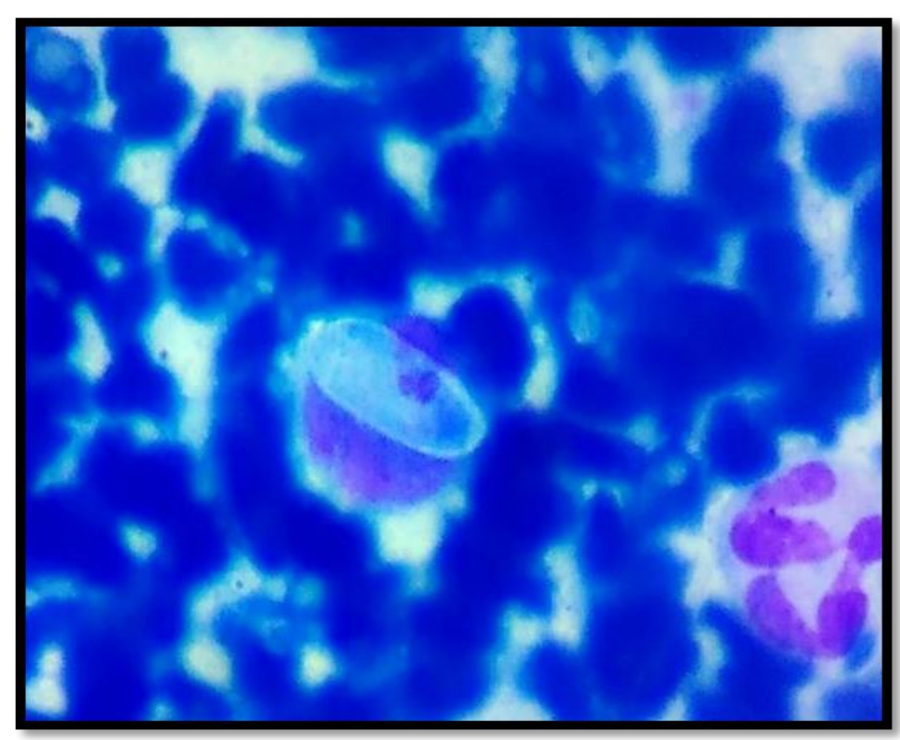


Figure.2 PCR amplified products of 18S rRNA gene of $H$. canis in 1.5 per cent agarose gel showing bands at $346 \mathrm{bp}$

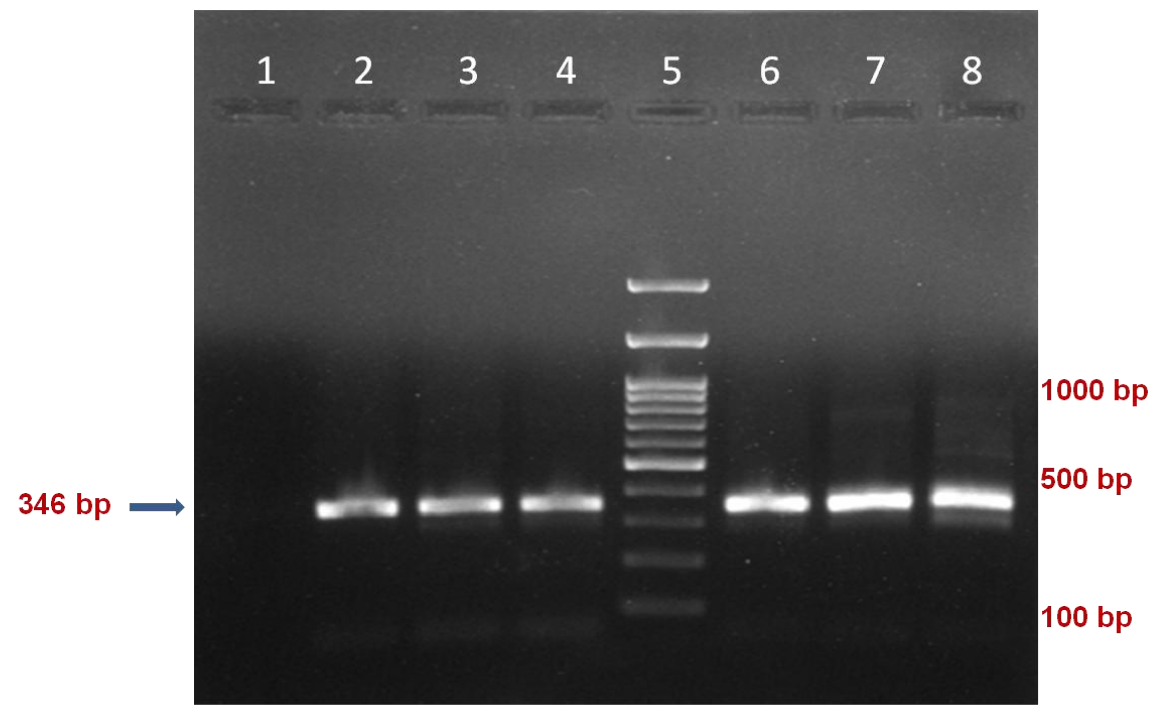

Lane 1 - Negative control, lane 2- Positive control, lane 5 - Ladder and lane 3,4,6,7 and 8- Test samples .

Figure.3 Phylogenetic relationship of 18S rRNA gene of $H$. canis with other published isolates (GenBank) and its homology and divergence

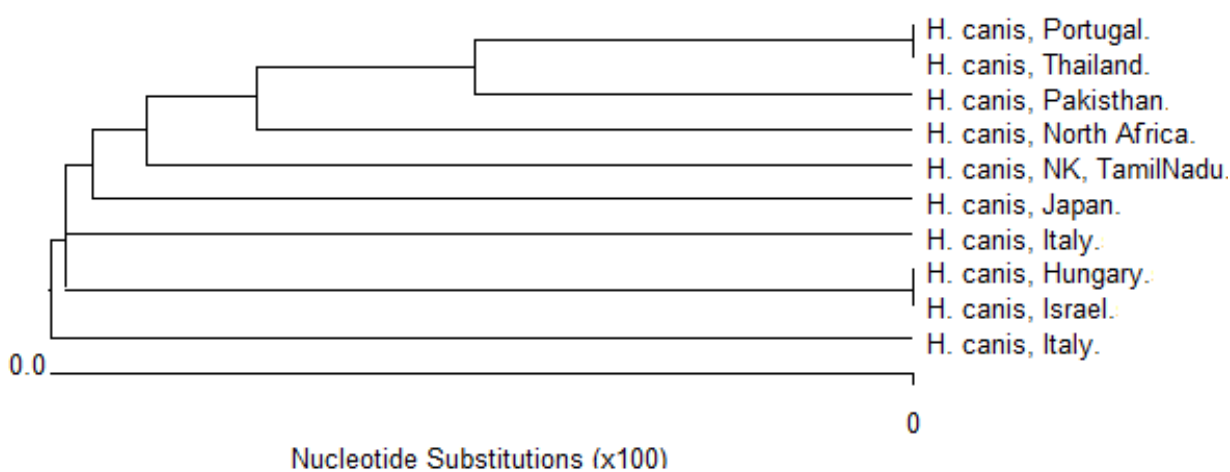

\begin{tabular}{|c|c|c|c|c|c|c|c|c|c|c|c|}
\hline \multicolumn{12}{|c|}{ Percent Identity } \\
\hline & 1 & 2 & 3 & 4 & 5 & 6 & 7 & 8 & 9 & 10 & \\
\hline 1 & & 99.6 & 100.0 & 100.0 & 100.0 & 100.0 & 100.0 & 100.0 & 100.0 & 100.0 & 1 \\
\hline 2 & 0.0 & & 99.6 & 99.6 & 99.6 & 99.6 & 99.6 & 99.6 & 99.6 & 99.6 & 2 \\
\hline 3 & 0.0 & 0.0 & & 100.0 & 100.0 & 100.0 & 100.0 & 100.0 & 100.0 & 100.0 & 3 \\
\hline 4 & 0.0 & 0.0 & 0.0 & & 100.0 & 100.0 & 100.0 & 100.0 & 100.0 & 100.0 & 4 \\
\hline 5 & 0.0 & 0.0 & 0.0 & 0.0 & & 100.0 & 100.0 & 100.0 & 100.0 & 100.0 & 5 \\
\hline 6 & 0.0 & 0.0 & 0.0 & 0.0 & 0.0 & & 100.0 & 100.0 & 100.0 & 100.0 & 6 \\
\hline 7 & 0.0 & 0.0 & 0.0 & 0.0 & 0.0 & 0.0 & & 100.0 & 100.0 & 100.0 & 7 \\
\hline 8 & 0.0 & 0.0 & 0.0 & 0.0 & 0.0 & 0.0 & 0.0 & & 100.0 & 100.0 & 8 \\
\hline 9 & 0.0 & 0.0 & 0.0 & 0.0 & 0.0 & 0.0 & 0.0 & 0.0 & & 100.0 & 9 \\
\hline 10 & 0.0 & 0.0 & 0.0 & 0.0 & 0.0 & 0.0 & 0.0 & 0.0 & 0.0 & & 10 \\
\hline & 1 & 2 & 3 & 4 & 5 & 6 & 7 & 8 & 9 & 10 & \\
\hline
\end{tabular}
H. canis, Hungary.
H. canis, Israel.
H. canis, Italia.
H. canis, Italy.
H. canis, Japan.
H. canis, NK, TamilNadu.
H. canis, North Africa.
H. canis, Pakisthan.
H. canis, Portugal.
$H$. canis, Thailand. 
In the present study, the sequence of $18 \mathrm{~S}$ rRNA of $H$. canis was found to have a complete homology (100.0\%) with isolates of Hungary, Italy, Japan, North Africa, Pakistan, Portugal and Thailand; however no published isolates are available for comparison with previous reports in India (Table 1 and Figure 3), where as Miranda et al., (2014) reported a similar finding with 99.0 per cent homology.

In the epidemiology, the tick vector involved in the transmission was found to be $H$. canis is $R$. sanguineus. A high prevalence of $H$. canis $(9.09 \%)$ was detected in the age group of above 4 years old (Aktas et al., 2013), however the parasite was reported in all age groups from pups younger than 3 months of age to old dogs in the previous study. Among the sex, males $(6.48 \%)$ were found to be highly susceptible (Gavazza et al., 2003; Tarun Kumar et al., 2012), however, no gender predilection for $H$. canis had been reported by Greene. Cross breeds (10.0\%) were found to be highly susceptible, where as more incidences of $H$. canis were recorded in pure breeds (Tarun Kumar et al. 2003) and no breed predilection in previous studies. A high incidence of $H$. canis was recorded in southwest monsoon $(41.66 \%)$ and this could be due to the prevailing high temperature and relative humidity which might have favoured the increased activity of tick vectors. However, there was no statistically significant difference found to exist among the different ages, sex and breeds of positive cases, and different seasons (Table 2).

In this study, the PCR was found to be a highly sensitive and useful tool in the detection of subclinical and asymptomatic carrier status of $H$. canis in dogs when compared to the conventional microscopic examination and routine screening by PCR would help in the identification of this parasite in carriers and thereby institution of suitable treatment for the control of disease.

\section{References}

Abd Rani, M., P.J. Irwin, M. Gatne, G.T. Coleman and Traub, R.J. 2010. Canine vector-borne diseases in India: a review of the literature and identification of existing knowledge gaps. Parasites Vectors, 3: 1-7.

Abd Rani, P.A.M., P.J. Irwin, G.T. Coleman, M. Gatne and Traub, R.J. 2011. Survey of canine tick-borne diseases in India. Parasites and Vectors, 4: 1-8.

Aktas, M., S. Ozubek and Ipek, D.N.S. 2013. Molecular investigations of Hepatozoon species in dogs and developmental stages of Rhipicephalus sanguineus. Parasitol. Res., 112: 2381-2385

Aydin, M.F., F. Sevinc and Sevinc, M. 2015. Molecular detection and characterization of Hepatozoon spp. in dogs from the Central part of Turkey. Ticks Tick Borne Dis., 6: 388-392.

Baneth, G. and Weigler, B. 1997. Retrospective case-control study of hepatozoonosis in dogs in Israel. J. Vet. Intern. Med. 11: 365-370.

Baneth, G., J.S. Mathew, V. Shkap, D.K. Macintire, J.R. Barta and Ewing, S.A. 2003. Canine hepatozoonosis: two disease syndromes caused by separate Hepatozoon spp. Trends in Parasitol., 19: 27-31.

Bhattacharjee, K. and Sarmah, P.C. Prevalence of haemoparasites in pet, working and stray dogs of Assam and North-East India: A hospital based study. Vet. World, 874-878.

Dwyer, O. 2011. Brazilian canine hepatozoonosis. Rev. Bras. Parasitol. Vet., 20: 181-193.

Gavazza, A., M. Bizzeti and Papini, R. 2003. Observations on dogs found naturally infected with Hepatozoon canis in Italy. Revue Med. Vet., 154: 565-571.

Greene, C.E., J.E. Sykes, G.E. Moore, R.E. Goldstein and Schultz, D. 2008. 
Infectious diseases of the dog and cats. $4^{\text {th }}$ edn.

Matsuu, A., S. Ono, H. Ikadi, T. Uchide, S. Imamura, M. Onuma, S. Okano and Higuchi, S. 2005. Development of a SYBR green real-time polymerase chain reaction assay for quantitative detection of Babesia gibsoni (Asian genotype) DNA. J. Vet. Diag. Investigation, 17: 569-573.

Miranda, R.L., L.H. Dwyer, J.R. Castro, B. Metzger, A.S. Rubini, A.V. Mundim, O. Eyal, D. Talmi-Frank, M.C. Cury and Baneth, G. 2014. Prevalence and molecular characterization of Hepatozoon canis in dogs from urban and rural areas in Southeast Brazil. Res. Vet. Sci., 97: 326-329.

Otranto, D., F. Dantas-Torres, S. Weigl, M.S. Latrofa, D. Stanneck, D. Decaprariis, G. Capelli and G. Baneth. 2011. Diagnosis of Hepatozoon canis in young dogs by cytology and PCR. Parasites Vectors, 4: 55.

Senthil Kumar, K., S. Vairamuthu and Kathiresan, D. 2009. Prevalence of haemoprotozoans in canines in Chennai city. Tamil Nadu J. Vet. Animal Sci., 5: 104-108.

Singh, H., M.H. Jyoti, N.K. Singh and S.S. Rath. 2012. Occurrence of parasitic infections in dogs in and around Ludhiana, Punjab (India). Appl. Biol. Res., 14: 108-110.

Tarun Kumar, N., Arora and Rajora, V.S. 2012. Hepatozoonosis and its therapeutic management in a dog. Intas Polivet., 138-139.

Vipan, K., S. Parvinder, S. Charanjeet, P. Heigo, B. Gagandeep and Hanish, S. 2015. Prevalence of Canine Babesiosis in Jalandhar District, Punjab, India. Res. J. Animal, Vet. Fishery Sci., 3: 6-8.

\section{How to cite this article:}

Kalaivanan Murugesan, Saravanan Subramanian, Palanivel Kondan Muthusamy and Ponnudurai, G. 2017. Detection of Hepatozoan canis in Dogs from Namakkal Region of Tamilnadu by Conventional and Molecular Approach. Int.J.Curr.Microbiol.App.Sci. 6(4): 811817. doi: https://doi.org/10.20546/ijcmas.2017.604.102 